\title{
Native, alien, cosmopolitan, or cryptogenic? A framework for clarifying the origin status of rotifers
}

\author{
Agnieszka Pociecha, Wojciech Solarz*, Kamil Najberek, Elżbieta Wilk-Woźniak
}

Institute of Nature Conservation, Polish Academy of Sciences, Av. A. Mickiewicza 33, 31-120 Kraków, Poland

\begin{abstract}
Among small organisms, it is often difficult to distinguish native from alien species because we cannot easily determine where they originate. They are often labelled cosmopolitan or cryptogenic, euphemisms that indicate that we are uncertain of their origin. This lack of information obscures our understanding of biogeography and ecosystem functioning, thus limiting our ability to control biological invasions. Here, we propose a simple method using existing data to improve assessments of freshwater Rotifera. We tested the usefulness of 8 of 10 attributes of alien species, taken from a framework originally designed for distinguishing alien marine crustaceans, and added one new attribute. We used this framework to verify the origin status of 16 rotifers referred to in the literature as alien, cosmopolitan, tropicopolitan, or new to Europe. We assigned the alien status to 11 species that scored positively for at least half of the attributes; only 3 of these species were previously classified as alien in the literature. Cryptogenic status was assigned to 5 species, including 1 previously considered to be alien in Europe. The most efficient predictors of alien origin status were 2 attributes: appearance in areas where not previously found, and relatively restricted distribution in the assessed area compared to the distributions of native species. We propose this method as a first step towards assessing the status of a species whose origin is unclear, before more labour-intensive tools such as genetic analysis are employed. The use of a formal protocol to screen the existing data makes the origin status assessment transparent, open to discussion and subject to revision as new information becomes available.
\end{abstract}

KEY WORDS: Rotifera $\cdot$ Biological invasions $\cdot$ Introduced species $\cdot$ Dispersal $\cdot$ Species ranges

\section{INTRODUCTION}

Recently, much effort has been put into developing scientifically sound risk-assessment protocols for different taxa and environments, formalizing the process of distinguishing between 'good' and 'bad' alien species; the latter having negative ecological or economic impacts (Brunel et al. 2010, Essl et al. 2011, Kumschick \& Richardson 2013, Vanderhoeven et al. 2015). Such a process must be rigorous and transparent, since listing species as alien may be legally binding and may have significant economic consequences, including import bans and/or high environmental management costs (European Commission 2014). However, while very important, determining

${ }^{*}$ Corresponding author: solarz@iop.krakow.pl the impact of alien species is only the second step in any such risk assessment. The first question to address is whether the species to be assessed is actually alien, or native to the area in which the risk assessment is being employed. Nativeness obviously excludes it from the scope of frameworks designed to help solve biological invasion problems.

Surprisingly few formal protocols have been proposed to distinguish between native and alien species, particularly when the data on the role of humans in their distribution is ambiguous (Webb 1985, Bean 2007). Determining the origin status of taxa can be particularly difficult for species whose records are scattered in distant parts of the world. With such an imperfect record it is difficult to reliably

() The authors 2016. Open Access under Creative Commons by Attribution Licence. Use, distribution and reproduction are unrestricted. Authors and original publication must be credited. 
delimit their distribution (Lee \& Patterson 2000, Finlay et al. 2004, Fontaneto et al. 2007, Fontaneto \& Brodie 2011, Wilk-Woźniak \& Najberek 2013, WilkWoźniak et al. 2016). It is even harder to determine whether each of the few records known for a given species lies within its natural range or whether some of them result from human-mediated introductions (Pyšek et al. 2004).

Apart from insufficient knowledge, failure to clarify the origin of small organisms is due in part to the common belief that their dispersal abilities are sufficient to allow natural colonization of suitable habitats anywhere on Earth. This long-standing view, capsuled as 'everything small is everywhere, but the environment selects' (Baas Becking 1934), was formalized as the cosmopolitan model (Finlay 2002, Fenchel \& Finlay 2004, de Wit \& Bouvier 2006, O'Malley 2007). Accordingly, small organisms are readily classified into a crude group of cosmopolitan or tropicopolitan species (Bean 2007, Segers \& De Smet 2008, Geller et al. 2010). The biogeography of small organisms is also easily dispensed with by classifying them as cryptogenic species whose presence at a given place cannot be unequivocally attributed to natural processes or to human intervention (Carlton 1996). Opponents of the concept of a wide distribution of small organisms would say that a significant fraction of such cosmopolitan or cryptogenic species might in fact be alien. The bias responsible for the failure of many scientists to acknowledge this possibility for small organisms has been termed the 'smalls rule of invasion ecology' (Wyatt \& Carlton 2002).

A direct result of the lack of due diligence in determining species status is that small organisms are underrepresented in, if not absent from, checklists and databases on alien species. Accurate estimates of the share of alien species in local communities are also basic to biogeography and to our understanding of the evolution and functioning of studied communities. A lack of knowledge of the invasion patterns of microorganisms severely hampers our ability to successfully manage current invasions and proactively prevent new ones (Preston 2009, Sakalidis et al. 2013).

We argue that distributional data on small organisms, however imperfect, may be enough of a basis for developing a simple framework to formalize distinctions between native and alien taxa. We use rotifers recorded in Europe as an example. The biogeography of this group has recently received considerable attention (Gómez et al. 2002, Fontaneto et al. 2007, 2012, Schröder \& Walsh 2007), although the problem of their origin status has rarely been addressed. Traditionally, rotifers were considered cosmopolitan, fitting the concept of ubiquitous species (Pejler 1977, Ruttner-Kolisko 1989, Artois et al. 2011), despite attempts by Green (1972) to bring some subtlety into the picture by classifying rotifers into cosmopolitan, cosmotropical, tropicopolitan, or Arctic-temperate species. A growing body of evidence has revealed interesting patterns of diversity and endemism in this group (Dumont 1983, Segers 2007 , 2008). Here, we propose a simple method to improve the assessment of freshwater Rotifera. Modifying an existing framework originally designed to distinguish alien marine crustaceans, we added a new attribute, and used this framework to verify the origin status of 16 rotifers.

\section{MATERIALS AND METHODS}

The a priori criterion for selecting species for our study was that their present-day distribution might result in part from human-mediated spread. Thus, we did not include species whose native status is well established. We did a thorough literature query, using 3 academic literature databases: the ISI Web of Knowledge, Scopus and Google Scholar. The following Boolean search string was used in each database: 'rotifer' AND ('cryptogenic' OR 'alien' OR 'exotic' OR 'non-native' OR 'non-indigenous'). The latter 3 terms are herein treated as synonyms of 'alien'. We found a total of 16 species whose occurrence in Europe was suggested to have resulted from human intervention (see Table 1, Figs. 1-4). The level of certainty of this assessment differed among the species; and in addition to the terms used in the search criteria, some of them were described in the literature using the descriptive terms new, cosmopolitan or tropicopolitan. For species described by multiple terms (new, cosmopolitan, cryptogenic, tropicopolitan, alien), we extracted the one that was closest to suggesting its alien European status (see Table 1, Figs. 1-4).

To determine the status of the selected Rotifera, we tested the usefulness of the framework developed by Chapman \& Carlton (1991), which they used to demonstrate that a few marine isopod species described from different parts of the world are in fact the same species - Synidotea laevidorsalis - which was introduced globally. The original framework included 10 attributes of alien species. We excluded 2 that referred to the role of the active and passive dispersal abilities of the species in the observed distribution; the reasons for this exclusion are explained in the 'Discussion'. For some attributes, a yes/no answer to a question was sufficient. Others required setting 
threshold values to obtain unequivocal negative or positive scores. Having no detailed guidance from Chapman \& Carlton (1991) on how to set such thresholds, we established the following guidelines for the 8 attributes we chose:

(1) Appearance in areas where not found previously. This criterion can be used if the assessed areas (e.g. lakes) have been sufficiently sampled in the past.

(2) Increase of new local records after appearance in areas where not found previously. The assessed area must have been sufficiently studied.

(3) Association with human mechanism(s) of dispersal. The species may be transported as a contaminant of imported commodities (e.g. fish for restocking; Dumont 1983), or as a stowaway in transport vectors (e.g. ships' ballast waters; Hulme et al. 2008). Positive score if the species occurs in Asia and North America, which are the most important donor areas for alien invertebrates and fish in European inland waters (Gherardi et al. 2009).

(4) Association with or dependence on other alien species. In the assessed area, the species is known to co-occur with other alien species or to be trophically dependent on them (e.g. Ejsmont-Karabin 2011). Positive score if the species is found in waterbodies from which assessments of biological invasions of other taxa are available.

(5) Prevalence on, or restriction to, human-transformed habitat(s). In the assessed area, the species occurs exclusively or predominantly in strongly transformed habitats (e.g. thermally or chemically polluted waterbodies). Positive score if at least $50 \%$ of the known European records are from human-transformed waterbodies.

(6) Relatively restricted distribution in the assessed area compared to the distributions of native species. Continental range limits of the species do not correspond with the biogeographic boundaries of related species; the species occurs in some locations (e.g. a lake) but not in similar adjacent locations that are inhabited by related species. The maximum number of European localities for a single species selected for our assessment was 15, with the majority of them clumped inside a limited range in a single country. Such a distribution is seen to be restricted when viewed against the usual ranges of native European rotifers.

(7) Isolated populations on different continents. A significant disjunction at the species level suggests that the species is alien, as the distribution of native cosmopolitan species is more or less continuous. We calculated the number of worldwide locations for each assessed species, treating locations within $500 \mathrm{~km}$ of each other as a single location (see Figs. 1b-4b). These values, divided by the number of all continents $(\mathrm{N}=7)$, yielded the mean value of the number of locations per continent for each species, ranging from 0.29 for the most isolated to 2.43 for the most widespread species (see Table 1). Species with values lower than $75 \%$ of the maximum value (i.e. with values $<1.82$ ) were assigned alien score in this category.

(8) Exotic evolutionary origin. Positive score if the closest relatives of the species are found outside of Europe.

We expanded Chapman \& Carlton's (1991) original framework to include a new attribute that can be assessed using robust information routinely collected with distribution records:

(9) Earliest record(s) of the species in the assessed area are from new or artificial environment(s); subsequent records can be from habitats with typical conditions.

To establish a score from this framework, each species judged to be alien is assigned an additional point (i.e. an alien point) to the species status; conversely, each species judged to be native is assigned a native point. In our study, we assigned alien origin status to rotifers that scored alien points for at least 5 of the 9 attributes. Species scoring below that threshold were classified as cryptogenic. Confidence in the correctness of status determination was taken to be highest for rotifers with the least equivocal scores (highest and lowest numbers of alien points), and less for species with intermediate values.

\section{RESULTS}

The number of alien points scored for the assessed species ranged between 3 and 7 , with 11 species judged affirmatively for at least 5 of the 9 attributes (Table 1); these were assigned alien status for Europe. According to the literature, only 3 of these species (Lecane shieli, Filinia minuta, Kellicottia bostoniensis) should be considered as alien in Europe (Table 1, Fig. 1). Alien status was confirmed with high confidence for $L$. shieli, and with low confidence for the other 2 species. For the 8 remaining rotifers that we assessed as alien in Europe, the literature assigns cosmopolitan or tropicopolitan origin status (Table 1, Figs. 2 \& 3). The alien status of Lecane inopinata, Brachionus variabilis and Lepadella apsida was assessed with high confidence, with medium confidence for 4 others, and low confidence for the remaining one. 


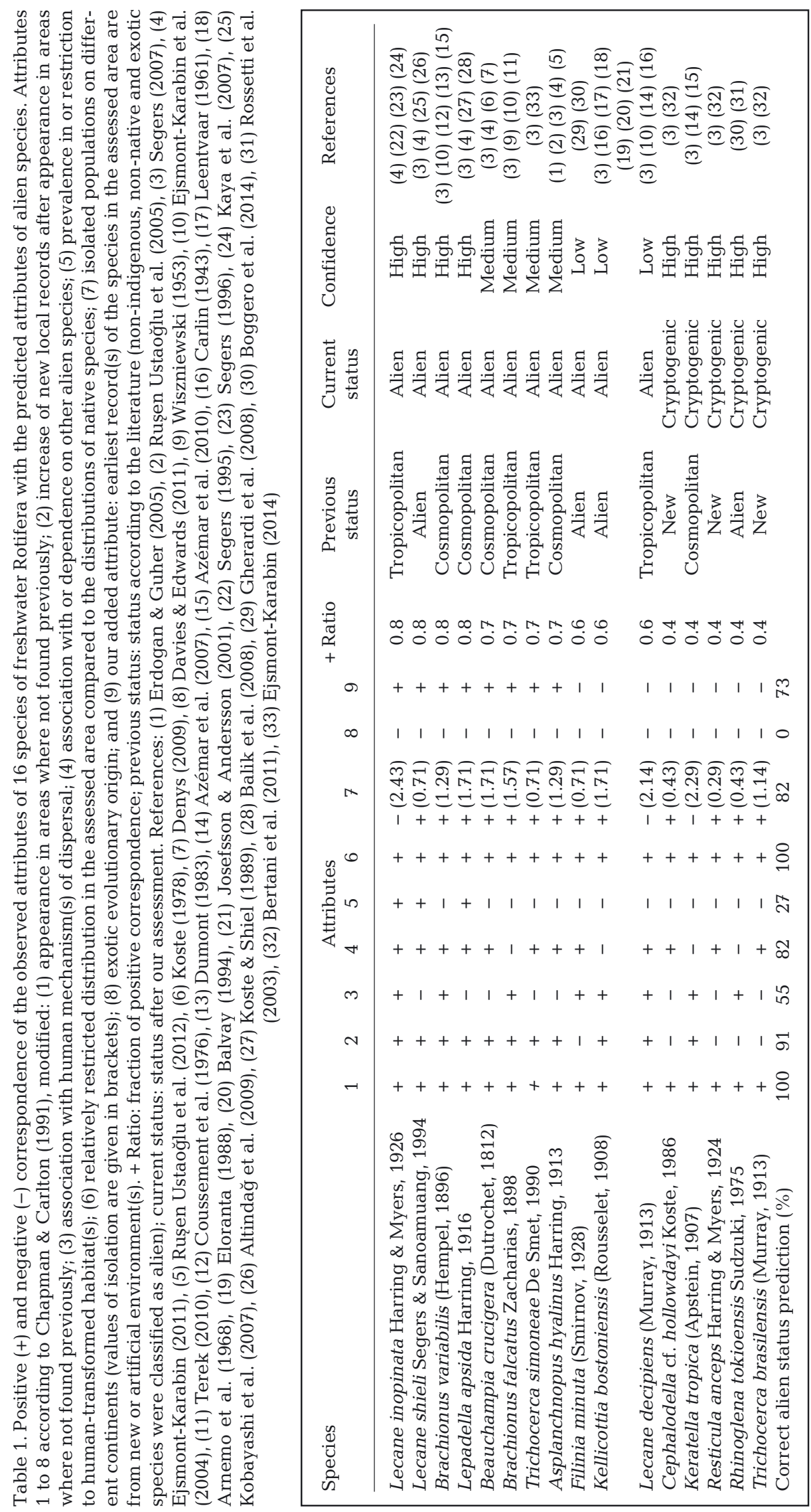

Five rotifers had positive scores for less than 5 of the attributes and were assigned cryptogenic European status (Table 1). According to the literature, one of these species-Rhinoglena tokioensis-is alien in Europe, whereas our assessment suggests, with high confidence, its cryptogenic origin (Table 1, Fig. 1). Of the 4 other rotifers we assessed as cryptogenic, one was previously described as cosmopolitan and 3 as new for Europe (Table 1, Fig. 4). Our assessments suggest local cryptogenic status, with high confidence (Table 1).

Of the attributes proposed by Chapman \& Carlton (1991) for classifying isopods, 'exotic evolutionary origin' (Attribute 8), turned out to be the least suitable criterion for predicting the alien status of the assessed Rotifera: none of the species that we ultimately classified as alien received positive scores for this (Table 1). 'Appearance in areas where not found previously' (Attribute 1), 'Relatively restricted distribution in the assessed area compared to the distributions of native species' (Attribute 6), both with $100 \%$ predictive power, and 'Increase of new records' after appearance in areas where not found previously' (Attribute 2) with $91 \%$ predictive power were the best predictors of the origin status of 11 rotifers ultimately classified as alien (Table 1).

\section{DISCUSSION}

The native or alien local status of a species often seems to result from an arbitrary decision of the assessor rather than from a rigorous assessment against a set of explicit criteria. Even classifying a species as cryptogenic, with unclear native/alien status, 




Kellicottia bostoniensis

- Filinia minuta

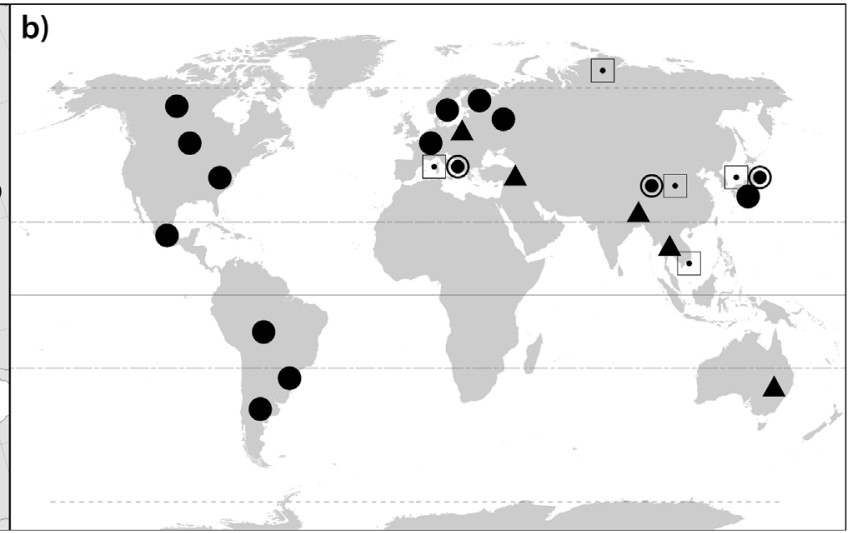

A Lecane shieli

(1) Rhinoglena tokioensis

Fig. 1. (a) European and (b) global distribution of rotifers considered alien in Europe. At the global level, locations closer than $500 \mathrm{~km}$ were treated as a single location

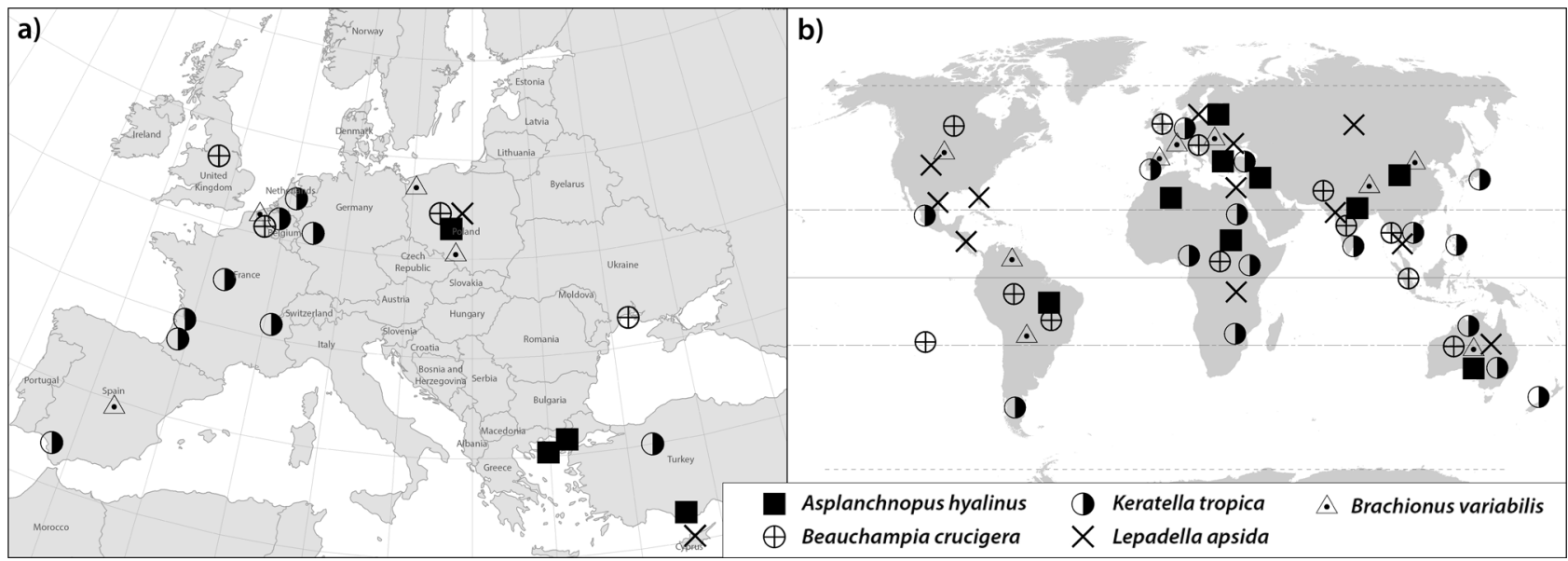

Fig. 2. (a) European and (b) global distribution of rotifers considered cosmopolitan. At the global level, locations closer than $500 \mathrm{~km}$ were treated as a single location

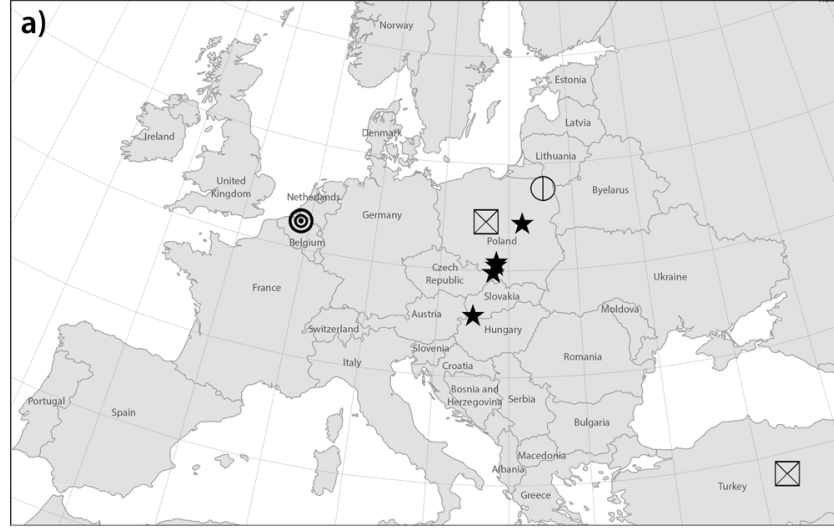

(2) Lecane decipiens

$\triangle$ Lecane inopinata

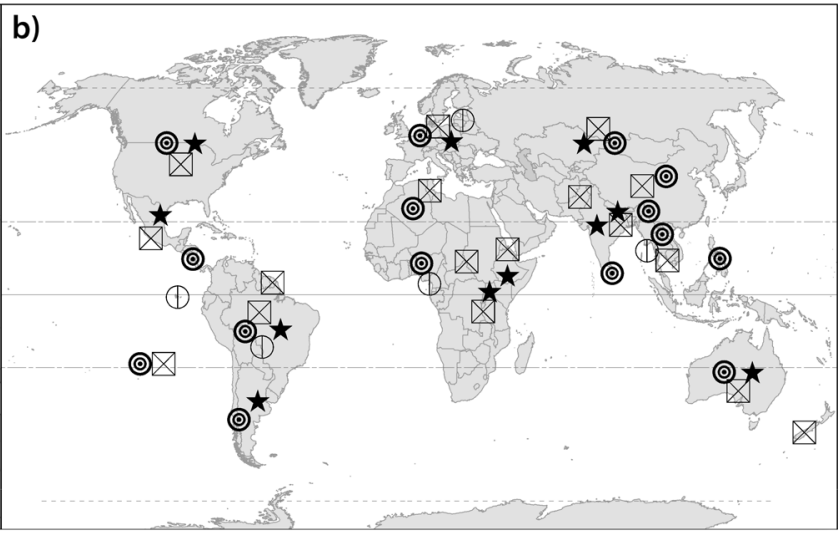

$\star$ Brachionus falcatus

(1) Trichocerca simoneae

Fig. 3. (a) European and (b) global distribution of rotifers considered tropicopolitan in Europe. At the global level, locations closer than $500 \mathrm{~km}$ were treated as a single location 


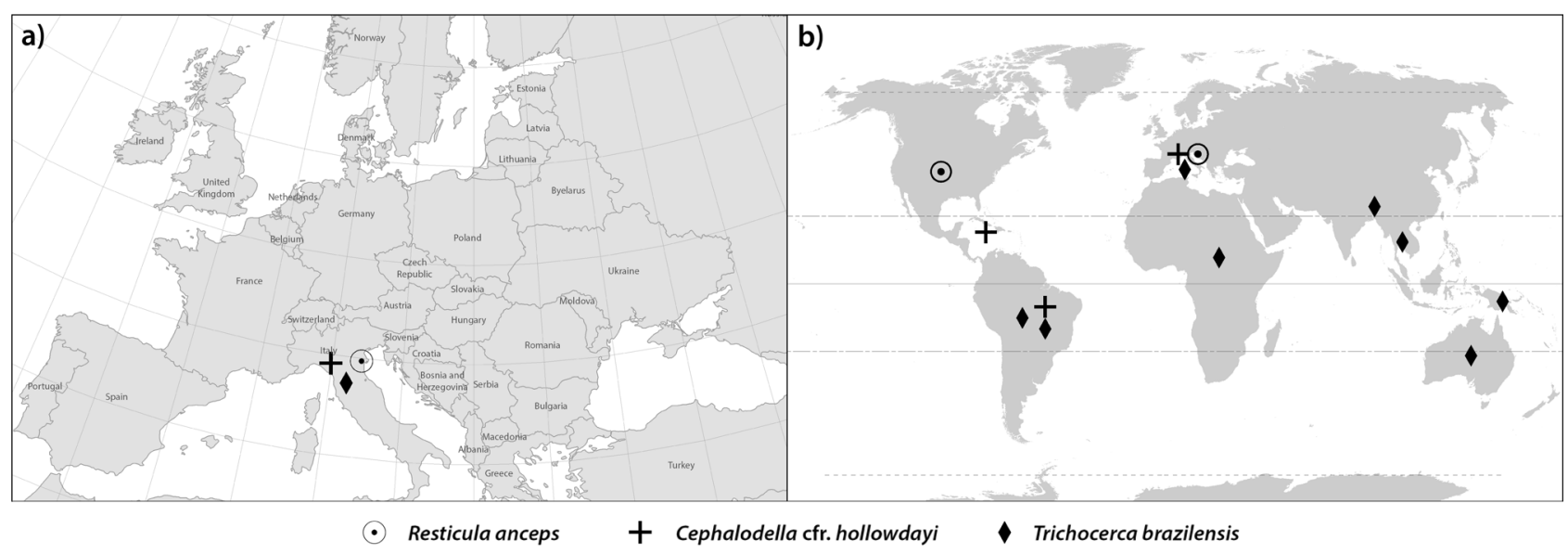

Fig. 4. (a) European and (b) global distribution of rotifers considered new in Europe. At the global level, locations closer than $500 \mathrm{~km}$ were treated as a single location

may reflect the researchers' lack of scrutiny rather than a systematic review of the available data. Often, the studies follow a circular route: information on origin status given by previous authors is uncritically followed and propagated through the years (Bean 2007). In addition, there is no uniform approach to the role of climate change, habitat transformation or long-distance spread by wind, water or migrating animals; these mechanisms of spread further blur the line between natural expansions and human-mediated introductions. Some authors consider those factors to be drivers of biological invasions of alien species, while others do not (Convention on Biological Diversity 2002, Green \& Figuerola 2005, Walther et al. 2009, Webber \& Scott 2012, Incagnone et al. 2015, Stoyneva 2016).

The framework that Chapman \& Carlton (1991) developed offers a formalized method for extracting aliens from the mass of cosmopolitans or cryptogenics. An advantage is that some of the attributes can be judged even on the basis of rough qualitative data. Other attributes (e.g. global isolation) can be optimally judged from quantitative data, with thresholds set for clear-cut decisions on negative or positive scores. In the absence of precise guidelines on how such thresholds should be set, and with insufficient information about the species, some level of subjectivity is inherent in such assessments. Moreover, depending on the taxon studied, the environment in which it occurs or the researcher's individual approach, some criteria may be combined, split, deleted or added.

For these reasons, we expanded Chapman \& Carlton's (1991) approach to include a confidence parameter for the outcomes of our assessment. For some rotifers, we demonstrated that despite the paucity of data, having a formal protocol to evaluate the data allowed us to find that the probability of human involvement in their current distribution is beyond reasonable doubt. In Europe, the confidence of this assessment is higher because the local rotifer fauna is better studied than in other areas; thus a lack of earlier records or a finding of limited species occurrence are less likely to be the result of research effort (Fontaneto et al. 2012).

We excluded 2 of the original criteria: insufficient active and passive dispersal abilities to account for the observed distribution. We do consider these attributes to be fundamental for distinguishing between natives and aliens, but we excluded them because unlike the other attributes, they provide direct, crowning evidence for a finding of origin status. Assessments should therefore start by answering whether a species could have arrived by means of active or passive dispersal (e.g. by wind, on drifting wood or on migrating birds). Negative answers should automatically mark the assessed species as alien, as the only possible means of its arrival other than active or passive dispersal must have been through human intervention. At this point the assessment of the origin status is complete and there is no need to fine-tune it by completing the remaining, less straightforward attributes of the framework, which can provide only circumstantial evidence of a taxon's origin.

Among the attributes proposed by Chapman \& Carlton (1991), the 'exotic evolutionary origin' criterion was the least efficient predictor of alien status of Rotifera. The reason is that the taxonomy and genetics of the species we selected are still poorly understood. However, in the face of the steady decline of classical research on taxonomy, biogeography and 
biology, molecular data are seen as the key to the future of invasion science (Geller et al. 2010). The level of rotifer diversity revealed by DNA studies may be significantly higher than that calculated on the basis of traditional taxonomy. For example, the apparent cosmopolitanism in the monogonont Brachionus plicatilis is actually due to the fact that it comprises a cryptic species complex, with as many as 22 morphologically similar taxa having more restricted distributions (Gómez et al. 2002). Moreover, a complex of at least 24 taxa was found in the British bdelloid Rotatoria rotatoria (Fontaneto et al. 2009). On the one hand, these findings suggest that the level of endemism among microorganisms may be higher than previously thought, which increases the probability of human intervention in the case of widely distributed species. However, some of the taxa distinguished from cryptic species complexes indeed have a very wide distribution (Gómez et al. 2002). Successful colonization of such vast areas seems relatively recent from an evolutionary time perspective, and it is usually attributed to the high capabilities of microorganisms for long-distance passive dispersal by natural vectors (Cáceres \& Soluk 2002, Gómez et al. 2002, Green \& Figuerola 2005, Incagnone et al. 2015). Given the stability of these vectors, however, propagule pressure (measured by the number of individuals of a species that arrive in an area) must have been massive over time. Thus, natural vectors have undoubtedly played a major role in shaping the distribution of small organisms, albeit mainly on an evolutionary time scale (Gómez et al. 2002, Ventura et al. 2014, Incagnone et al. 2015).

Species that disperse via natural means are still being discovered, but the occurrence of these is usually temporally and/or geographically restricted. Thus, an earlier irregular presence might have been easily overlooked, even in well-studied areas (Schröder \& Walsh 2007). The situation is different, however, when newly detected species start spreading soon after their discovery. It is less justified to attribute their presence in a given area to natural vectors. These vectors have been operating for long enough to provide ample time for such species to have arrived and already spread far in the past. This holds true even if there are long lags between vector initiation and the time a species begins to utilize it, and between the arrival of a species into a new area, adaptation to local conditions, and the onset of the invasion (Crooks 2011).This means that recent range expansions in areas far from the boundaries of the current occurrence could be assumed to be the result of anthropogenetic introduction.
Our study underlines the need for a systematic reassessment of the distribution patterns of many organisms, particularly for groups in which the share of species classified as cryptogenic or cosmopolitan is suspiciously high. The use of formal protocols for collation of previously collected (though usually scattered) data will make origin status assessments transparent, open to discussion, and subject to revision as new information becomes available. Such frameworks should be applied as cost-effective steps to screen for cases that require further investigation with more sophisticated molecular genetics tools (Grabowski et al. 2012). Our approach is a versatile one: the set of criteria and threshold levels for classifying species as alien can be tailored for application to other taxa and other environments. We suggest that a given set of criteria should be verified at different spatial scales, thereby validating whether they are sufficiently robust to use as formal benchmarks in examining the structure, evolution and functioning of communities, and in managing biological invasions.

Acknowledgements. We thank Diego Fontaneto and 3 anonymous reviewers for their useful comments on the earlier version of the manuscript. We also thank Michael Jacobs for line-editing the manuscript for submission. This study was supported by the Polish National Science Center (project no. N N305 374939) and co-funded by the Institute of Nature Conservation (Polish Academy of Sciences) and by Doctus the Małopolska Province Stipend Fund for Doctoral Candidates (application no. ZS.4112-125/11).

\section{LITERATURE CITED}

Altindağ A, Segers H, Kaya M (2009) Some Turkish rotifer species studied using light and scanning electron microscopy. Turk J Zool 33:73-81

Arnemo R, Berzins B, Grönberg B, Mellgren I (1968) The dispersal in Swedish waters of Kellicottia bostoniensis (Rousselet) (Rotatoria). Oikos 19:351-358

Artois T, Fontaneto D, Hummon WD, McInnes SJ, Todaro MA, Sørensen MV, Zullini A (2011) Ubiquity of microscopic animals? Evidence from the morphological approach in species identification. In: Fontaneto D (ed) Biogeography of microscopic organisms: Is everything small everywhere? Cambridge University Press, Cambridge, p 245-249

Azémar F, Van Damme S, Meire P, Tackx M (2007) New occurrence of Lecane decipiens (Murray, 1913) and some other alien rotifers in the Schelde estuary (Belgium). Belg J Zool 137:75-83

Azémar F, Maris T, Mialet B, Segers H, Van Damme S, Meire P, Tackx M (2010) Rotifers in the Schelde estuary (Belgium): a test of taxonomic relevance. J Plankton Res 32:981-997

Baas Becking LGM (1934) Geobiologie of inleiding tot de milieukunde. Van Stockum and Zoon, The Hague

> Balvay G (1994) First record of the rotifer Kellicottia 
bostoniensis (Rousselet, 1908) in France. J Plankton Res 16:1071-1074

Balık S, Ruşen Ustaoğlu M, Özdemir Mis D, Aygen C, Taşdemir A, İlhan A (2008) First observations on the aquatic fauna inhabiting freshwaters ponds of Turkish Republic of Northern Cyprus. EU J Fish Aquat Sci 25: 347-351 (in Turkish with English Abstract)

Bean T (2007) A new system for determining which plant species are indigenous in Australia. Aust Syst Bot 20:1-43

> Bertani I, Segers H, Rossetti G (2011) Biodiversity down by the flow: new records of monogonont rotifers for Italy found in the Po River. J Limnol 70:321-328

- Boggero A, Basset A, Austoni M, Barbone E and others (2014) Weak effects of habitat type on susceptibility to invasive freshwater species: an Italian case study. Aquat Conserv 24:841-852

> Brunel S, Branquart E, Fried G, Van Valkenburg J and others (2010) The EPPO prioritization process for invasive alien plants. EPPO Bull 40:407-422

> Cáceres CE, Soluk DA (2002) Blowing in the wind: a field test of overland dispersal and colonization by aquatic invertebrates. Oecologia 131:402-408

Carlin B (1943) Die Planktonrotatorien des Motalaström. Zur Taxonomie und Ökologie der Planktonrotatorien. Medd Lunds Univ Limnol Instn 5:1-256

Carlton JT (1996) Biological invasions and cryptogenic species. Ecology 77:1653-1655

> Chapman JW, Carlton JT (1991) A test of criteria for introduced species: the global invasion by the isopod Synidotea laevidorsalis (Miers, 1881). J Crustac Biol 11:386-400

Convention on Biological Diversity (2002) COP 6 Decision VI/23: Alien species that threaten ecosystems, habitats or species. Sixth Meeting of the Conference of the Parties to the Convention on Biological Diversity, 7-19 April 2002, The Hague. www.cbd.int/decision/cop/?id=7197

Coussement M, De Henau AM, Dumont HJ (1976) Brachionus variabilis Hempel and Asplanchna girodi de Guerne, two rotifer species new to Europe and Belgium, respectively. Biologisch Jaarboek (Dodonaea) 44:118-122

Crooks JA (2011) Lag times. In: Simberloff D, Rejmánek M (eds) Encyclopedia of biological invasions. University of California Press, Berkeley, CA, p 404-410

Davies C, Edwards F (2011) CEH code list for recording the macroinvertebrates in fresh water in the British Isles. NERC/Centre for Ecology and Hydrology, Wallingford

de Wit $\mathrm{R}$, Bouvier $\mathrm{T}$ (2006) 'Everything is everywhere, but, the environment selects'; what did Baas Becking and Beijerinck really say? Environ Microbiol 8:755-758

Denys L (2009) Een a posteriori typologie van stilstaande wateren in Vlaanderen. Rapporten van het Instituut voor Natuur- en Bosonderzoek 2009 (34), Instituut voor Natuur- en Bosonderzoek, Brussels

Dumont HJ (1983) Biogeography of rotifers. Hydrobiologia 104:19-30

Ejsmont-Karabin J (2011) Does invasion of Vallisneria spiralis L. promote appearance of rare and new rotifer (Rotifera) species in littoral of the lakes heated by power station (Konin lakes, W. Poland)? Pol J Ecol 59:201-207

Ejsmont-Karabin J (2014) Rotifer invasion? On appearance and abundance of tropical species in lakes of northeastern Poland. Pol J Ecol 62:821-827

Ejsmont-Karabin J, Radwan S, Bielańska-Grajner I (2004) Monogononta - atlas of species, 32B. In: Radwan S (ed) Rotifers (Rotifera): freshwater fauna of Poland, Vol 32. Oficyna wydawnicza Tercja, Uniwersytet Łódzki, p 147-448 (in Polish)

Eloranta P (1988) Kellicottia bostoniensis (Rousselet), a planktonic rotifer species new to Finland. Ann Zool Fenn 25:249-252

> Erdogan S, Guher H (2005) The Rotifera fauna of Gala Lake (Edirne-Turkey). Pak J Biol Sci 8:1579-1583

> Essl F, Nehring S, Klingenstein F, Milasowzky N, Nowack C, Rabitsch W (2011) Review of risk assessment systems of IAS in Europe and introducing the German-Austrian Black List Information System (GABLIS). J Nat Conserv 19:339-350

European Commission (2014) Regulation (EU) No. 1143/ 2014 of the European Parliament and of the Council of 22 October 2014 on the prevention and management of the introduction and spread of invasive alien species. Off $\mathrm{J}$ Eur Union L317:35-55

Fenchel T, Finlay JB (2004) The ubiquity of small species: patterns of local and global diversity. Bioscience 54: $777-784$

Finlay BJ (2002) Global dispersal of free-living microbial eukaryote species. Science 296:1061-1063

- Finlay BJ, Esteban GF, Fenchel T (2004) Protist diversity is different? Protist 155:15-22

Fontaneto D, Brodie J (2011) Why biogeography of microorganisms? In: Fontaneto D (ed) Biogeography of microscopic organisms. Is everything small everywhere? Cambridge University Press, Cambridge, p 3-10

Fontaneto D, Herniou E, Barraclough TG, Ricci C (2007) On the global distribution of microscopic animals: new worldwide data on bdelloid rotifers. Zool Stud 46:336-346

Fontaneto D, Kaya M, Herniou EA, Barraclough TG (2009) Extreme levels of hidden diversity in microscopic animals (Rotifera) revealed by DNA taxonomy. Mol Phylogenet Evol 53:182-189

Fontaneto D, Barbosa AM, Segers H, Pautasso M (2012) The 'rotiferologist' effect and other global correlates of species richness in monogonont rotifers. Ecography 35:174-182

Geller JB, Darling JA, Carlton JT (2010) Genetic perspectives on marine biological invasions. Annu Rev Mar Sci 2: 367-393

Gherardi F, Bertolino S, Bodon M, Casellato S and others (2008) Animal xenodiversity in Italian inland waters: distribution, modes of arrival, and pathways. Biol Invasions 10:435-454

Gherardi F, Gollasch S, Minchin D, Olenin S, Panov V (2009) Alien invertebrates and fish in European inland waters. In: Drake JA (ed) Handbook of alien species in Europe. Springer, Dordrecht, p 81-92

Gómez A, Serra M, Carvalho GR, Lunt DH (2002) Speciation in ancient cryptic species complexes: evidence from the molecular phylogeny of Brachionus plicatilis (Rotifera). Evolution 56:1431-1444

Grabowski M, Rewicz T, Bacela-Spychalska K, Konopacka A, Mamos T, Jażdżewski K (2012) Cryptic invasion of Baltic lowlands by freshwater amphipod of Pontic origin. Aquat Invasions 7:337-346

Green AJ (1972) Latitudinal variation in associations of planktonic Rotifera. J Zool 167:31-39

Green AJ, Figuerola J (2005) Recent advances in the study of long-distance dispersal of aquatic invertebrates via birds. Divers Distrib 11:149-156

Hulme PE, Bacher S, Kenis M, Klotz S and others (2008) Grasping at the routes of biological invasions: a framework for integrating pathways into policy. J Appl Ecol 45: 403-414 
Incagnone G, Marrone F, Barone R, Robba L, Naselli-Flores L (2015) How do freshwater organisms cross the 'dry ocean'? A review on passive dispersal and colonization processes with a special focus on temporary ponds. Hydrobiologia 750:103-123

Josefsson M, Andersson B (2001) The environmental consequences of alien species in the Swedish lakes Mälaren, Hjälmaren, Vänern and Vättern. Ambio 30:514-521

Kaya M, Yiğit S, Altındağ A (2007) Rotifers in Turkish inland waters. Zool Middle East 40:71-76

Kobayashi T, Shiel RJ, Segers H (2007) First record of the rotifer Lecane shieli Segers and Sanoamuang, 1994 from Australia. Aust Zool 34:181-183

Koste W (1978) Rotatoria. Die Riidertiere Mitteleuropas, 2nd edn. Gebrüder Borntraeger, Stuttgart

Koste W, Shiel RJ (1989) Classical taxonomy and modern methodology. Hydrobiologia 186/187:279-284

Kumschick S, Richardson D (2013) Species-based risk assessments for biological invasions: advances and challenges. Divers Distrib 19:1095-1105

Lee WJ, Patterson DJ (2000) Heterotrophic flagellates (Protista) from marine sediments of Botany Bay, Australia. J Nat Hist 34:483-562

Leentvaar P (1961) Quelques rotateurs rares observes en Hollande. Hydrobiologia 18:245-251

O'Malley MA (2007) The nineteenth-century roots of 'everything is everywhere'. Nat Rev Microbiol 5:647-651

Pejler B (1977) On the global distribution of the family Brachionidae (Rotatoria). Arch Hydrobiol Suppl 53: 255-306

Preston CD (2009) The terms 'native' and 'alien' - a biogeographical perspective. Prog Hum Geogr 33:702-711

Pyšek P, Richardson DM, Rejmánek M, Webster GL, Williamson M, Kirschner J (2004) Alien plants in checklists and floras: towards better communication between taxonomists and ecologists. Taxon 53:131-143

Rossetti G, Tirreni F, Viglioli S, Ferrar I (2003) Ricerche ecologiche in un ambiente acquatico della golena del Po nei pressi di Casalmaggiore. Studi Trent Sci Nat Acta Biol 80:193-200

Ruşen Ustaoğlu M, Balık S, Özdemir Mis D, Aygen C (2005) The zooplankton of some mountain lakes in the Taurus Range (Turkey). Zool Middle East 34:101-108

Rus̨en Ustaoğlu M, Özdemir Mis D, Aygen C (2012) Observations on zooplankton in some lagoons in Turkey. J Black Sea/Mediterranean Environ 18:208-222

Ruttner-Kolisko A (1989) Problems in the taxonomy of rotifers, exemplified by the Filinia longiseta-terminalis complex. Hydrobiologia 186/187:291-298

Sakalidis ML, Slippers B, Wingfield BD, Hardy GEStJ, Burgess TI (2013) The challenge of understanding the origin, pathways and extent of fungal invasions: global populations of the Neofusicoccum parvum-N. ribis species complex. Divers Distrib 19:873-883

Editorial responsibility: Anna Metaxas,

Halifax, Nova Scotia, Canada
Schröder T, Walsh EJ (2007) Cryptic speciation in the cosmopolitan Epiphanes senta complex (Monogononta, Rotifera) with the description of new species. Hydrobiologia 593:129-140

Segers H (1995) Zoogeography of littoral Rotifera, with special reference to the Lecanidae. PhD thesis, Universitet Gent, Belgium

Segers H (1996) The biogeography of littoral Lecane Rotifera. Hydrobiologia 323:169-197

Segers H (2007) Annotated checklist of the rotifers (Phylum Rotifera) with notes on nomenclature, taxonomy and distribution. Zootaxa 1564:1-104

Segers H (2008) Global diversity of rotifers (Rotifera) in freshwater. Hydrobiologia 595:49-59

> Segers H, De Smet W (2008) Diversity and endemism in Rotifera: a review, and Keratella Bory de St Vincent. Biodivers Conserv 17:303-316

Stoyneva MP (2016) Allochthonous planktonic algae recorded during the last 25 years in Bulgaria and their possible dispersal agents. Hydrobiologia 764:53-64

Terek J (2010) New and rare species of Rotifers (Rotatoria) in Slovakia. Folia Fauni Slov 15:143-146

- Vanderhoeven S, Adriaens T, D'hondt B, Van Gossum H and others (2015) A science-based approach to tackle invasive alien species in Belgium - the role of the ISEIA protocol and the Harmonia information system as decision support tools. Manage Biol Invasions 6:197-208

> Ventura M, Petrusek A, Miro A, Hamrova E, Bunay D, De Meester L, Mergeay J (2014) Local and regional founder effects in lake zooplankton persist after thousands of years despite high dispersal potential. Mol Ecol 23: 1014-1027

- Walther GR, Roques A, Hulme PE, Sykes MT and others (2009) Alien species in a warmer world: risks and opportunities. Trends Ecol Evol 24:686-693

Webb DA (1985) What are the criteria for presuming native status? Watsonia 15:231-236

Webber BL, Scott JK (2012) Rapid global change: implications for defining natives and aliens. Glob Ecol Biogeogr 21:305-311

Wilk-Woźniak E, Najberek K (2013) Towards clarifying the presence of alien algae in inland waters: Can we predict places of their occurrence? Biologia 68:838-844

Wilk-Woźniak E, Solarz W, Najberek K, Pociecha A (2016) Alien cyanobacteria: an unsolved part of the 'expansion and evolution' jigsaw puzzle? Hydrobiologia 764:65-79

Wiszniewski J (1953) Materiaux relatifs a la nomenclature et a la bibliographie des Rotiferes. Pol Arch Hydrobiol 2: $1-260$

Wyatt T, Carlton JT (2002) Phytoplankton introductions in European coastal waters: Why are so few invasions reported? In: F Briand (ed) CIESM workshop monographs, Vol 20. The Mediterranean Science Commission, Monaco, p 41-46

Submitted: November 13, 2014; Accepted: December 3, 2015 Proofs received from author(s): January 18, 2016 